\title{
Synthesis and Characterization of New Surface Active Azo Initiators for Radical Reactions
}

\author{
Milos Sedlak*, and Klaus Tauer ${ }^{2}$ \\ ${ }^{1}$ Department of Organic Chemistry, University of Pardubice, Cs legii 565, 53210 Pardubice, Czech \\ Republic \\ Tel.: 42040603 7015, Fax: 42040603 7068, E-mail: Milos.Sedlak@upce.cz \\ ${ }^{2}$ Department of Colloid Chemistry, Max-Planck-Institute for Colloids and Interfaces, Forschungcam- \\ pus Golm, 14424 Potsdam, Germany
}

Tel.: 49331567 9511, Fax: 49331567 9502, E-mail: Klaus.Tauer@mpikg-golm.mpg.de

*Author to whom correspondence should be addressed.

Received: 10 January 2000 / Accepted: 10 May 2000 / Published: 18 May 2000

\begin{abstract}
The synthesis of a water soluble azo initiators from 2,2'-azodiisobutyronitrile (AIBN) was performed in three steps: reaction of dinitrile with aromatic alcohols in the presence of $\mathrm{HCl}$ to form bisiminoesters hydrochlorides which are hydrolyzed to the esters and final regioselective sulfonation of the aromatic esters. The thermal decomposition of the azo initiators obtained leads to formation of two surface active radicals which can start the chain reaction.
\end{abstract}

Keywords: Surface Active Azo Initiators, sulfonation, emulsion polymerization.

\section{Introduction}

One of the domains of free radical chemistry is industrial polymerization of alkenes. At present, emulsion polymerization has become increasingly important because of replacement of organic solutions by more environment-friendly aqueous dispersions [1]. On the other hand, however, despite synthetic chemists' skepticism, it was also proved that the radical reaction can lead to carbon-carbon bond formation in chemoselective, regioselective, and even stereoselective ways [2]. For said radical

(C) 2000 by MDPI (http://www.mdpi.org). Reproduction is permitted for noncommercial purposes. 
reactions to take place, it is necessary to synthesize water soluble initiators. The aim of this work is to prepare water soluble azo initiators from 2,2'-azodiisobutyronitrile (AIBN), the initiators having surface activity necessary for stabilization of the latex particles [1].

Chemical modifications of AIBN must be based on reactions that can occur below $30^{\circ} \mathrm{C}$ to prevent decomposition of the starting AIBN. The most appropriate reaction seems to be the Pinner synthesis $[3,4]$ consisting in reaction of the starting nitrile with excess anhydrous alcohol and hydrogen chloride to give the respective iminoester hydrochloride. The latter can be subsequently hydrolyzed to ester. The ester, which contains a benzene ring, can then be sulfonated in an anhydrous medium (Scheme 1). Another possible modification of the nitrile group consists in its transformation into an amide group via a Ritter reaction [5].

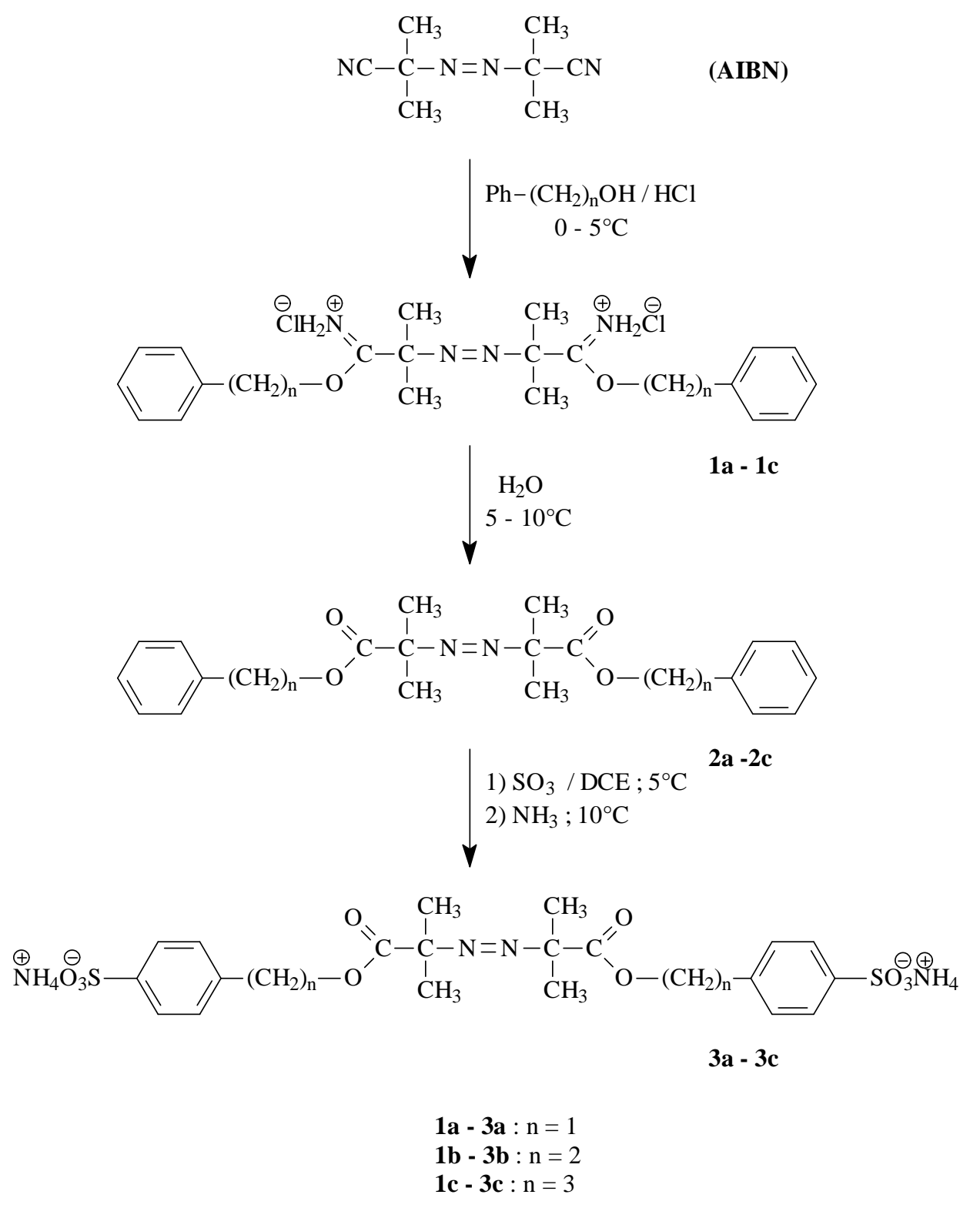

Scheme 1. 


\section{Results and Discussion}

Bisiminoester hydrochlorides 1a-1c were prepared by reaction of $1 \mathrm{~mol}$ AIBN with $15 \mathrm{~mol}$ of the corresponding alcohol (benzyl alcohol, 2-phenyl-1-ethyl alcohol, 3-phenyl-1-propyl alcohol) saturated with gaseous hydrogen chloride at $0-5^{\circ} \mathrm{C}$. The separated crystalline hydrochlorides 1a-1c were collected by filtration and immediately hydrolyzed to give the corresponding esters $\mathbf{2 a - 2 c}$. The yield of 2,2'-azodiisobutyrate 2a was only 15\%, 2,2'-azodiisobutyramide and benzyl chloride being isolated as the side products. Our finding corresponds with the earlier described easy nucleophilic substitution of stabilized carbocations with chloride ion, where the Pinner reaction of imidates from branched alcohols gives the respective amides and chloroderivatives [6]. The yields of bis(2-phenylethyl) 2,2'azodiisobutyrate (2b) and bis(3-phenylpropyl) 2,2'-azodiisobutyrate were 77 and 75\%, respectively.

The esters thus prepared (2a-2c) were subsequently sulfonated in a chemo- and regioselective way, $v i z$. at the 4-position of the benzene ring, by treatment with sulfur trioxide in 1,2-dichlorethane at $5^{\circ} \mathrm{C}$. After removing excess sulfur trioxide, the resulting sulfonic acids (3a-3c) were transformed to their ammonium salts: diammonium 2,2'-azobis[p-(2-methylpropanoyloxymethyl)benzene-sulfonate] (3a; yield 67\%), diammoniun 2,2'-azobis[p-( $\beta$-(2-methylpropanoyloxy)ethyl)benzene-sulfonate] (3b; yield $87 \%$ ) and diammonium 2,2'-azobis[p-( $\chi$-(2-methylpropanoyloxy)propyl)-benzenesulfonate](3c; yield $52 \%)$. The other AIBN modification chosen made use of the Ritter reaction, consisting in the transformation of a suitable olefin or tertiary alcohol by treatment with sulfuric acid into the respective carbocation, which is subsequently attacked by the free electron pair at the nitrogen atom of a nitrile group and finally producesa an $\mathrm{N}$-alkyl amide [5]. In order to introduce the solubilizing group in the same reaction step, we adopted 3-methyl-2-butenoic acid as the source of the carbocation. After neutralization and recrystallization from water, we isolated disodium 6,6'-azobis(3,3,6-trimethyl-4-aza-5oxopentanoate) (4) (Figure 1).<smiles>CC(C)(CC(=O)[O-])NC(=O)C(C)(C)N=NC(C)(C)C(=O)NC(C)(C)CC(=O)O[Na]</smiles>

4

Figure 1.

The emulsion polymerization of styrene was studied in more detail with the help of a RM - 2S reaction calorimeter. For instance, the phenetyl derivative $\mathbf{3 b}(\mathrm{n}=2)$ has been used to prepare monodisperse poly(styrene) latexes in the $200 \mathrm{~nm}$ size range. The rate of polymerization can be controlled by the initiator concentration. The figure shows the heat flow- time curves for varying amounts of $\mathbf{3 b}$. It is clearly seen that with increasing amount of $\mathbf{3 b}$ a distinct gel peak appears in the last stage of the polymerization. The overall enthalpy of polymerization was determined to be $(58.50 \pm 0.05) \mathrm{kJ} / \mathrm{mol}$ which corresponds to the literature value [8]. 


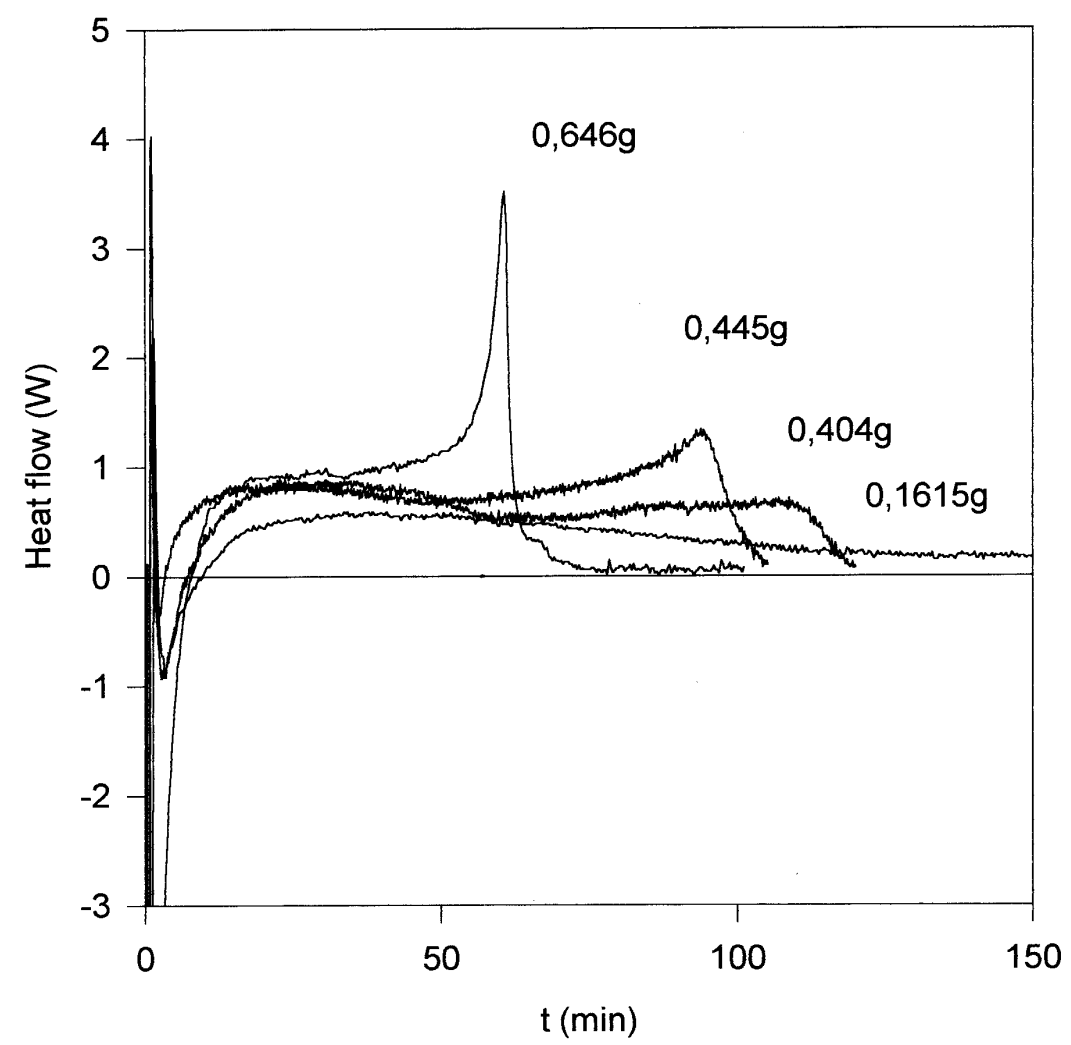

Figure 2. Heat flow - time curves for the emulsion polymerization of styrene with varying amounts of $\mathbf{3 b}$.

\section{Conclusion}

It is possible to synthesize novel water soluble initiators for radical reaction from AIBN using classical organic chemistry. Surface active initiators (INISURF's) fulfill two different tasks in an emulsion polymerization: the start of the polymerization as well as the stabilization of the polymer particles. The thermal decomposition of the azo-group leads to the formation of two surface active radicals which start the chain reaction. However, the primary radical recombination is very fast due to the low mobility of the adsorbed primary radicals. Nevertheless, our new INISURF's can still be used to carry out emulsion polymerizations.

\section{Experimental}

\section{General}

Unless otherwise stated, all the chemicals used were obtained from Aldrich and used without further purification. Melting points were measured on a Kofler hot-stage instrument and are uncorrected. The 
${ }^{1} \mathrm{H}$ and ${ }^{13} \mathrm{C}$ NMR spectra were measured on an AMX 360 Bruker spectrometer at 360.14 and 90.57 $\mathrm{MHz}$, respectively at $25^{\circ} \mathrm{C}$ in hexadeuteriodimethyl sulfoxide (DMSO-d ${ }_{6}$ ) or in deuterium oxide $\left(\mathrm{D}_{2} \mathrm{O}\right)$. In the cases where DMSO- $\mathrm{d}_{6}$ was used the chemical shifts are referred to the middle signal of the solvent multiplet $\left[\delta\left({ }^{1} \mathrm{H}\right) 2.55\right.$ and $\left.\delta\left({ }^{13} \mathrm{C}\right) 39.6\right]$. The internal reference used for the deuterium oxide solutions was sodium 4,4-dimethyl-4-silapentane-1-sulfonate (DSS).

General procedure of the reaction of the AIBN with alcohols

A mixture of AIBN (65.6 g, $0.4 \mathrm{~mol})$ and an appropriate alcohol $(6 \mathrm{~mol})$ was saturated with $\mathrm{HCl}$ gas at $3^{\circ} \mathrm{C}$ for $4 \mathrm{~h}$ (until no crystals occur). The mixture was stirred at $0^{\circ} \mathrm{C}$ for $24 \mathrm{~h}$. After further cooling to $-15^{\circ} \mathrm{C}$ the corresponding iminoesters $\mathbf{1 a}, \mathbf{1 b}$ or $\mathbf{1 c}$ were separated by filtration and washed with cold acetone. Dry iminoesters were decomposed with $4 \mathrm{~L}$ of ice-water mixture. After hydrolysis (overnight) the crude esters $\mathbf{2 a}, \mathbf{2 b}$ or $\mathbf{2 c}$ were recrystallized from acetone at $25^{\circ} \mathrm{C}$.

\section{Dibenzyl-2,2'-azodiisobutyrate (2a)}

Yield 15\%, m.p. $44-46^{\circ} \mathrm{C}$ (dec.); TLC : silica gel plates, ethyl acetate, $\mathrm{R}_{\mathrm{F}}=0.47 ;{ }^{1} \mathrm{H}$ NMR (DMSO$\left.\mathrm{d}_{6}\right) \delta: 1.35\left(\mathrm{~s} ; 6 \mathrm{H}, \mathrm{CH}_{3}\right) ; 5.09\left(\mathrm{~s} ; 2 \mathrm{H}, \mathrm{CH}_{2}\right) ; 7.30\left(\mathrm{~m} ; 5 \mathrm{H}\right.$-arom). ${ }^{13} \mathrm{C}$ NMR (DMSO-d $)$ ) $22.5\left(\mathrm{CH}_{3}\right)$; $66.1\left(\mathrm{CH}_{2}\right) ; 75.0(\mathrm{Cq}) ; 127.0(\mathrm{CH}-$ arom $) ; 136.1\left(\mathrm{Cq}\right.$-arom); $171.9(\mathrm{C}=\mathrm{O})$. Calculated for $\mathrm{C}_{22} \mathrm{H}_{26} \mathrm{~N}_{2} \mathrm{O}_{4}$ (382.5): $69.09 \% \mathrm{C}, 6.85 \% \mathrm{H}, 7.32 \% \mathrm{~N}$. Found: $69.14 \% \mathrm{C}, 6.81 \% \mathrm{H}, 7.46 \% \mathrm{~N}$.

2,2'-Azodiisobutyramide (isolated as a by product) m.p. $80-82^{\circ} \mathrm{C}$ (dec.); TLC: silica gel plates, ethyl acetate, $\mathrm{R}_{\mathrm{F}}=0.12 ;{ }^{1} \mathrm{H}$ NMR $\left(\mathrm{DMSO}-\mathrm{d}_{6}\right) \delta: 1.34\left(\mathrm{~s} ; 3 \mathrm{H}, \mathrm{CH}_{3}\right) ; 7.20\left(\mathrm{~d} ; 2 \mathrm{H}, \mathrm{NH}_{2}\right)$. Calculated for $\mathrm{C}_{8} \mathrm{H}_{16} \mathrm{~N}_{4} \mathrm{O}_{2}(200.2): 47.99 \% \mathrm{C}, 8.05 \% \mathrm{H}, 27.98 \% \mathrm{~N}$. Found: $48.12 \% \mathrm{C}, 8.08 \% \mathrm{H}, 28.10 \% \mathrm{~N}$.

\section{Bis(2-phenylethyl)-2,2'-azodiisobutyrate (2b)}

Yield 77\%, m.p. $48-49^{\circ} \mathrm{C}$ (dec.); TLC: silica gel plates, ethyl acetate, $\mathrm{R}_{\mathrm{F}}=0.63 ;{ }^{1} \mathrm{H}$ NMR (DMSO$\left.\mathrm{d}_{6}\right) \delta: 1.62\left(\mathrm{~s} ; 6 \mathrm{H}, \mathrm{CH}_{3}\right) ; 2.84\left(\mathrm{t} ; 2 \mathrm{H}, \mathrm{CH}_{2} \mathrm{Ph}\right) ; 4.24\left(\mathrm{t} ; 2 \mathrm{H}, \mathrm{CH}_{2} \mathrm{O}\right) ; 7.23\left(\mathrm{~m} ; 5 \mathrm{H}\right.$-arom). ${ }^{13} \mathrm{C}$ NMR $\left(\mathrm{DMSO}_{6}\right)$ \&: $22.5\left(\mathrm{CH}_{3}\right) ; 35.1\left(\mathrm{CH}_{2} \mathrm{Ph}\right) ; 66.1\left(\mathrm{CH}_{2} \mathrm{O}\right) ; 76.0(\mathrm{Cq}) ; 128.0(\mathrm{CH}$-arom); 138.5 (Cq-arom); $173.1(\mathrm{C}=\mathrm{O})$. Calculated for $\mathrm{C}_{24} \mathrm{H}_{30} \mathrm{~N}_{2} \mathrm{O}_{4}(410.5)$ : $70.22 \% \mathrm{C}, 7.37 \% \mathrm{H}, 6.82 \% \mathrm{~N}$. Found: $70.34 \% \mathrm{C}$, $7.41 \% \mathrm{H}, 6.95 \% \mathrm{~N}$.

\section{Bis(3-phenylpropyl)-2,2'-azodiisobutyrate (2c)}

Yield 75\%, m.p. $29-31^{\circ} \mathrm{C}$; TLC: silica gel plates, ethyl acetate, $\mathrm{R}_{\mathrm{F}}=0.68 ;{ }^{1} \mathrm{H}$ NMR $\left(\mathrm{DMSO}-\mathrm{d}_{6}\right) \delta$ : $1.38\left(\mathrm{~s} ; 6 \mathrm{H}, \mathrm{CH}_{3}\right) ; 1.81\left(\mathrm{~m} ; 2 \mathrm{H}_{,} \mathrm{CH}_{2}\right) ; 2.59\left(\mathrm{t} ; 2 \mathrm{H}, \mathrm{CH}_{2} \mathrm{Ph}\right) ; 4.02\left(\mathrm{t} ; 2 \mathrm{H}, \mathrm{CH}_{2} \mathrm{O}\right) ; 7.21(\mathrm{~m} ; 5 \mathrm{H}$-arom $) .{ }^{13} \mathrm{C}$ NMR (DMSO-d $)$ ): $23.1\left(\mathrm{CH}_{3}\right) ; 31.1\left(\mathrm{CH}_{2}\right) ; 32.1\left(\mathrm{CH}_{2} \mathrm{Ph}\right) ; 64.6\left(\mathrm{CH}_{2} \mathrm{O}\right) ; 76.0(\mathrm{Cq}) ; 128.1(\mathrm{CH}$-arom); 142.1 (Cq-arom); $172.9(\mathrm{C}=\mathrm{O})$. Calculated for $\mathrm{C}_{26} \mathrm{H}_{34} \mathrm{~N}_{2} \mathrm{O}_{4}$ (438.6): $71.21 \% \mathrm{C}, 7.81 \% \mathrm{H}, 6.39 \% \mathrm{~N}$. Found: $71.28 \% \mathrm{C}, 7.77 \% \mathrm{H}, 6.46 \% \mathrm{~N}$. 
General procedure of sulfonation of esters $\mathbf{2 a}, \mathbf{2} \mathbf{b}$ and $\mathbf{2 c}$

A solution of the ester $(0.024 \mathrm{~mol})$ in 1,2-dichloroethane $(50 \mathrm{~g})$ was added dropwise with stirring to a solution of freshly distilled sulfur trioxide $(20 \mathrm{~g}, 0.25 \mathrm{~mol})$ in 1,2 -dichloroethane $(70 \mathrm{~g})$ at $3-5^{\circ} \mathrm{C}$ for $30 \mathrm{~min}$. After the was complete addition the solutions were stirred for one hour at $10^{\circ} \mathrm{C}$ to give a twophase reaction mixture. After separation the top layer was removed and the bottom phase was washed 8 times with 1,2-dichloroethane (50 g). The bottom layer was neutralized with an aqueous solution of ammonia (22\%) with cooling to $15^{\circ} \mathrm{C}$ and vigorous mixing. The precipitated diammonium salts $\mathbf{3 a}, \mathbf{3 b}$ or $3 \mathbf{c}$ were isolated by filtration and purified by crystallization from methanol-water mixtures $\left(25^{\circ} \mathrm{C}\right)$.

Diammonium 2,2'-azobis[p-(2-methylpropanoyloxymethyl)benzenesulfonate] (3a)

Yield 67\%, ${ }^{1} \mathrm{H}$ NMR $\left(\mathrm{D}_{2} \mathrm{O}\right) \delta: 1.18\left(\mathrm{~s} ; 6 \mathrm{H}, \mathrm{CH}_{3}\right) ; 5.18\left(\mathrm{~s} ; 2 \mathrm{H} \mathrm{CH}_{2}\right) ; 7.38(\mathrm{~d} ; \mathrm{J}=7.7 \mathrm{~Hz}, 2 \mathrm{H}$-arom), $7.71\left(\mathrm{~d} ; \mathrm{J}=7.7 \mathrm{~Hz}, 2 \mathrm{H}\right.$-arom). ${ }^{13} \mathrm{C} \mathrm{NMR}\left(\mathrm{D}_{2} \mathrm{O}\right) \delta: 22.1\left(\mathrm{CH}_{3}\right) ; 60.8\left(\mathrm{CH}_{2}\right) ; 75.6(\mathrm{qC}$; quaternary carbon); 128.3 (CH-arom); 131.4 (CH-arom); 142.1 (qC -arom); 142.9 (qC-arom); $175.3(\mathrm{C}=\mathrm{O})$. Calculated for $\mathrm{C}_{22} \mathrm{H}_{32} \mathrm{~N}_{4} \mathrm{O}_{10} \mathrm{~S}_{2}(576.6): 45.82 \% \mathrm{C}, 5.59 \% \mathrm{H}, 9.72 \% \mathrm{~N}, 11.12 \% \mathrm{~S}$. Found: $45.89 \% \mathrm{C}, 5.57 \% \mathrm{H}, 9.87 \% \mathrm{~N}$, $11.28 \% \mathrm{~S}$.

Diammonium 2,2'-azobis[p-(ß-(2-methylpropanoyloxy)ethyl)benzenesulfonate] (3b)

Yield 87\%, ${ }^{1} \mathrm{H}$ NMR $\left(\mathrm{D}_{2} \mathrm{O}\right) \delta: 1.21\left(\mathrm{~s} ; 6 \mathrm{H}, \mathrm{CH}_{3}\right) ; 2.97\left(\mathrm{t} ; 2 \mathrm{H}, \mathrm{CH}_{2}-\mathrm{Ph}\right) ; 4.35\left(\mathrm{t} ; 2 \mathrm{H}, \mathrm{CH}_{2} \mathrm{O}\right) ; 7.32$ (d; $\mathrm{J}=7.8 \mathrm{~Hz}, 2 \mathrm{H}$-arom); $7.68\left(\mathrm{~d} ; \mathrm{J}=7.8 \mathrm{~Hz}, 2 \mathrm{H}\right.$-arom). ${ }^{13} \mathrm{C}$ NMR $\left(\mathrm{D}_{2} \mathrm{O}\right) \delta: 22.2\left(\mathrm{CH}_{3}\right) ; 34.8\left(\mathrm{CH}_{2} \mathrm{Ph}\right)$; $66.2\left(\mathrm{CH}_{2} \mathrm{O}\right) ; 75.9$ (qC); 126.2 (CH-arom); 130.1 (CH-arom); 141.5 (qC-arom); 142.6 (qC-arom); $175.2(\mathrm{C}=\mathrm{O})$. Calculated for $\mathrm{C}_{24} \mathrm{H}_{36} \mathrm{~N}_{4} \mathrm{O}_{10} \mathrm{~S}_{2}(604.7)$ : $47.67 \% \mathrm{C}, 6.00 \% \mathrm{H}, 9.27 \% \mathrm{~N}, 10.60 \% \mathrm{~S}$. Found : $47.74 \% \mathrm{H}, 5.98 \% \mathrm{H}, 9.32 \% \mathrm{~N}, 10.73 \% \mathrm{~S}$.

Diammonium 2,2'-azobis[p-( $\chi$-(2-methylpropanoyloxy)propyl)benzenesulfonate] (3c)

Yield 52\%, ${ }^{1} \mathrm{H}$ NMR $\left(\mathrm{D}_{2} \mathrm{O}\right) \delta: 1.30\left(\mathrm{~s} ; 6 \mathrm{H}, \mathrm{CH}_{3}\right) ; 1.92\left(\mathrm{~m} ; 2 \mathrm{H}, \mathrm{CH}_{2}\right), 2.67\left(\mathrm{t} ; 2 \mathrm{H}, \mathrm{CH}_{2} \mathrm{Ph}\right) ; 4.24(\mathrm{t}$; $\left.2 \mathrm{H}, \mathrm{CH}_{2} \mathrm{O}\right) ; 7.35$ (d; J = $7.8 \mathrm{~Hz}, 2 \mathrm{H}$-arom); $7.75\left(\mathrm{~d} ; \mathrm{J}=7.8 \mathrm{~Hz}, 2 \mathrm{H}\right.$-arom). ${ }^{13} \mathrm{C}$ NMR $\left(\mathrm{D}_{2} \mathrm{O}\right) \delta: 22.1$ $\left(\mathrm{CH}_{3}\right) ; 35.1\left(\mathrm{CH}_{2}\right) ; 36.4\left(\mathrm{CH}_{2}\right) ; 66.5\left(\mathrm{CH}_{2} \mathrm{O}\right) ; 75.8(\mathrm{qC}) ; 126.8$ (CH-arom); 130.3 (CH-arom); 141.4 (qC-arom); 142.8 (qC-arom); $175.3(\mathrm{C}=\mathrm{O})$. Calculated for $\mathrm{C}_{26} \mathrm{H}_{40} \mathrm{~N}_{4} \mathrm{O}_{10} \mathrm{~S}_{2}(632.7): 49.35 \% \mathrm{C}, 6.37 \% \mathrm{H}$, $8.85 \%$ N, $10.13 \%$ S. Found : $49.29 \% \mathrm{C}, 6.38 \% \mathrm{H}, 8.93 \% \mathrm{~N}, 10.26 \% \mathrm{~S}$.

Disodium 6,6'-azobis(3,3,6-trimethyl-4-aza-5-oxoheptanoate) (4)

A mixture of AIBN (4.1 g, $0.025 \mathrm{~mol})$, 3-methyl-2-butenoic acid (10 g, $0.10 \mathrm{~mol})$ and glacial acetic $(50 \mathrm{~mL})$ acid was treated with $\mathrm{H}_{2} \mathrm{SO}_{4}(98 \%, 50 \mathrm{~mL})$ added over $60 \mathrm{~min}$. The temperature was kept at $30^{\circ} \mathrm{C}$. The mixture was allowed to stand at room temperature overnight and then poured onto ice 
(200g). The precipitated acid was isolated by filtration and neutralized with a solution of $\mathrm{NaOH}$. Recrystalization from water $\left(25^{\circ} \mathrm{C}\right)$ gave colorless crystals $(2.5 \mathrm{~g} ; 23 \%) .{ }^{1} \mathrm{H}$ NMR $\left(\mathrm{D}_{2} \mathrm{O}\right) \delta: 1.44(\mathrm{~s} ; 6 \mathrm{H}$, $\left.\mathrm{CH}_{3}\right) ; 1.55\left(\mathrm{~s} ; 6 \mathrm{H} \mathrm{CH}_{3}\right) ; 2.66\left(\mathrm{~s} ; 2 \mathrm{H}, \mathrm{CH}_{2}\right) ;{ }^{13} \mathrm{C} \mathrm{NMR}\left(\mathrm{D}_{2} \mathrm{O}\right) \delta: 19.8\left(\mathrm{CH}_{3}\right) ; 23.4\left(\mathrm{CH}_{3}\right) ; 46.9(\mathrm{qC}) ; 50.1$ $\left(\mathrm{CH}_{2}\right) ; 72.4(\mathrm{qC}) ; 173.2(\mathrm{CONH}) ; 177.4(\mathrm{COO})$. Calculated for $\mathrm{C}_{18} \mathrm{H}_{30} \mathrm{~N}_{4} \mathrm{O}_{6} \mathrm{Na}_{2}$ (444.4): 48.65\% , $6.80 \% \mathrm{H}, 12.61 \% \mathrm{~N}$. Found: $48.68 \% \mathrm{C}, 6.97 \% \mathrm{H}, 12.74 \% \mathrm{~N}$.

The emulsion polymerization of styrene

A mixture of styrene (10 g) and water (95 g) was heated with stirring in a reaction calorimeter (RM - 2S, heat flow/ heat balance system; ChemiSens AB, Lund, Sweden). At a temperature of $90^{\circ} \mathrm{C}$ a solution of $3 \mathbf{b}(0.646 \mathrm{~g}$; $0445 \mathrm{~g} ; 0.404 \mathrm{~g} ; 0.1615 \mathrm{~g})$ in water $(5 \mathrm{~g})$ was injected into the calorimeter. The heat-flow-time dependence was recorded. The particle size of the latex obtained after polymerization (150 min) was analyzed by electron microscopy (Rast's electron microscope DSM 940A, Zeiss).

Acknowledgements: The authors wish to acknowledge the financial support provided by the MaxPlanck Society and the University of Pardubice.

\section{References and Notes}

1. Tauer, K. Reactive surfactants. NATO ASI Ser., Ser. E 1997, 463-476, Kluwer.

2. Giese, B. Stereoselective syntheses with carbohydrate radicals. Pure Appl. Chem. 1988, 60, 16551658 .

3. Pinner, A. Ueber die Umwandlung der Nitrile in Imide. Chem. Ber. 1883, 16, 1643-1655.

4. Walz, R.; Bömer, B.; Heitz, W. Monomeric and Polymeric Azoinitiators. Macromol. Chem. 1977, $178,2527-2534$.

5. Ritter, J.J.; Minieri, P.P. A New Reaction of Nitriles. I. Amides from Alkenes and Mononitriles. J. Am.Chem. Soc. 1948, 70, 4045-4048.

6. Neilson, D.G. In The Chemistry of Amidines and Imidates; Patai S., Ed.; Wiley: London, 1979; Chapter 9, p 74.

7. Garth, P.R. U.S. Patent 4131619 (Chem. Abstr. 1994, 90, 87038).

8. Bessiere, J.M.; Boutevin, B.; Loubet, O.; Pietrasanta, Y. Synthesis and Characterization of a Disulfonated Azo Initiator - Application to the Polymerization of Acrylic Acid. Macromol. Chem. Phys. 1994, 195, 845-853.

Samples Availability: Available from the authors.

(C) 2000 by MDPI (http://www.mdpi.org). Reproduction is permitted for noncommercial purposes. 